\title{
Effect of Organic and Inorganic Sources of Nutrients on NPK Uptake by Rice Crop at Various Growth Periods
}

\author{
Mohana Rao Puli, P R K Prasad, *M Jayalakshmi and **B Srihari Rao \\ Department of Soil Science and Agricultural Chemistry, Agricultural College, Bapatla, Andhra Pradesh, India \\ *Central Research Institute for Dryland Agriculture, Hyderabad - 500 070, Telangana, India \\ **BCT Krishi Vigyan Kendra, Vizag, Telangana, India \\ e-mail: mohanpulioo7@gmail.com
}

Received: 04 March 2016; Revised accepted: 04 January 2017

\section{A B S T R A C T}

A field experiment was conducted for two consecutive years (2011-2012 and 2012-2013) as doctoral research on fine texture soils of Agricultural College Farm, Bapatla to find out the effect of different sources of nutrients on NPK uptake by rice at various growth periods. The experiment was laid out in a randomized block design in kharif season with four treatments and replicated five times. The treatments consisted of $M_{1}$ (RDF - Control), $M_{2}$ (10t FYM ha ${ }^{-1}+$ RDF), $M_{3}$ (1.5t vermicompost ha ${ }^{-1}+$ RDF), $M_{4}$ (Green manuring + RDF). The NPK uptake by rice at various growth periods was significantly increased with the application of $100 \%$ NPK in combination with FYM @ 10 h $^{-1}$. However, it was on par with that of green manuring together with $100 \%$ NPK during both the years of the study.

Key words: Rice crop, Organic sources, Inorganic sources, NPK uptake, Growth periods

$\mathrm{T}$ The high cost of fertilizers and unstable crop production call for substituting part of the inorganic fertilizers by locally available low cost organic sources like FYM, green manuring and vermicompost in an integrated manner for sustainable production and to maintain soil health. Integrated nutrient management involving conjunctive use of organic, inorganic and crop residues may improve the soil productivity (Patra et al. 2000, Kumar et al. 2001) and system productivity become sustainable (Raju and Reddy 2001).

\section{MATERIALS AND METHODS}

In order to investigate the influence of different sources of nutrients on NPK uptake by rice, the present experiment was conducted in the field number 49A and 49B of the Agricultural College Farm, Bapatla, during the years 201112 and 2012-13, respectively. Prior to preparatory cultivation of the experimental site, soil samples from 0 to $15 \mathrm{~cm}$ depth were collected at random and a composite soil sample during both the years was analyzed for different physico-chemical properties. The results of the soil analytical data indicated that the experimental soil is clay and sandy clay during first and second year, respectively in texture, slightly alkaline in reaction, low in organic carbon ( 0.52 and $0.50 \%$ during first and second year, respectively) and available nitrogen (175.6 and $159.8 \mathrm{~kg} \mathrm{ha}^{-1}$ during first and second year, respectively), and high in available phosphorus (95.3 and $93.9 \mathrm{~kg} \mathrm{P}_{2} \mathrm{O}_{5} \mathrm{ha}^{-1}$ during first and second year, respectively) and potassium (960.0 and 925.6 $\mathrm{kg} \mathrm{K}_{2} \mathrm{O} \mathrm{ha}^{-1}$ during first and second year, respectively).

The experiment consisted of four treatments viz. $\mathrm{M}_{1}$ (RDF- Control), $\mathrm{M}_{2}$ (10t FYM ha $\left.{ }^{-1}+\mathrm{RDF}\right), \mathrm{M}_{3}$ (1.5t vermicompost ha $\left.^{-1}+\mathrm{RDF}\right), \mathrm{M}_{4}$ (Green manuring $+\mathrm{RDF}$ ). The experiment is laid out in RBD and replicated five times. The recommended fertilizer dose was applied as 160:40:40kg N, $\mathrm{P}_{2} \mathrm{O}_{5}$ and $\mathrm{K}_{2} \mathrm{O} \mathrm{ha}^{-1}$. A popular super fine rice cultivar BPT 5204 (Samba Mashuri) was selected for kharif season. It is a cross between (GEB-24 x TN-1) and Mashuri. FYM and vermicompost were added 7 days before transplanting of rice on dry weight basis. Dhaincha crop was raised with the seed rate of $60 \mathrm{~kg} \mathrm{ha}^{-1}$ in individual plots and it was incorporated 7 days before transplanting of rice as green manure at flowering stage. Nitrogen was applied in the form of urea in three splits, first split at the time of transplanting, second split at 30 DAT and third split at 60 DAT. Phosphorus was applied in the form of SSP as basal dose before transplanting. Potassium was applied in the farm of MoP in two splits, first split as basal before transplanting and second split at 60 DAT.

Plant samples of rice were collected from destructive rows at various growth periods and five randomly selected plants at harvest stage. The samples were first dried in shade and then in hot air oven at $65^{\circ} \mathrm{C}$. The plant samples were ground in willey mill and stored in labeled brown paper bags for analysis. The grain samples were also processed and 
stored in similar fashion. $\mathrm{N}$ content in plant samples was determined by micro Kjeldahl method (Piper 1966).

Di-acid extract was prepared as per the method outlined by Jackson (1973). It was carried out using a 9:4 mixture of $\mathrm{HNO}_{3}: \mathrm{HClO}_{4}$. The predigestion of sample was done by using $10 \mathrm{ml}$ of $\mathrm{HNO}_{3} \mathrm{~g}^{-1}$ sample. This di-acid extract was used to determine $\mathrm{P}$ and $\mathrm{K}$ content in the plant and grain samples. Phosphorus was determined spectrophotometrically by vanadomolybdate phosphoric acid yellow color method as described by Jackson (1973) from di-acid extract. Potassium was estimated from di-acid extract by using flame photometer (Jackson 1973). From the chemical analytical data, uptake of the each nutrient was calculated as shown below:

$$
\text { Nutrient uptake }\left(\mathrm{kg} \mathrm{ha}^{-1}\right)=\frac{\begin{array}{c}
\text { Nutrient content }(\%) \times \text { dry } \\
\text { weight in kg ha }
\end{array}}{100}
$$

\section{RESULTS AND DISCUSSION}

The chemical composition of plants is a translation of the conditions under which they complete their life cycle fully or a part of it. The chemical composition is a net summary of all the changes either positive or negative, which are faced by the plants. The nutrient uptake is directly or indirectly affected by many factors like total concentration as well as available quantity of different nutrients, root development, aeration, water potential, climatic conditions and other related soil parameters. Beside all these, the presence of a nutrient in available form for the plant has to play the deciding role. Application of nutrients in readily available forms rapidly enhances the availability of that nutrient in the soil but all is neither taken up by plants nor remain permanently in available form. The dynamic processes are always in operation in the soil or accelerated and a major part of the applied nutrients are rapidly converted in to unavailable forms. Some fraction of it may be permanently fixed but when organic materials are applied, the overall fertility status of the soil is buildup the total reserve of nutrients is increased and a stage for enhanced availability is set up. Ayalew and Dejene (2012) stated that integrated nutrient management is the best approach to supply adequate and balanced nutrients and increase crop productivity in an efficient and environmentally benign manner, without sacrificing soil productivity of future generations. Mithun et al. (2007), Srinivasan and Angayarkanni (2000) reported that uptake of nutrients was improved by the application of integrated use of organic manures and inorganic fertilizers compared to RDF alone.

\section{$N$ uptake by rice}

$\mathrm{N}$ uptake by rice at $30 \mathrm{DAT}, 60 \mathrm{DAT}, 90 \mathrm{DAT}$ and maturity during both the years of study is presented in the (Table 1) and predicted in the (Fig 1). Irrespective of growth stage of rice and year of the study, the treatments those received organics along with the $\operatorname{RDF}\left(\mathrm{M}_{2}, \mathrm{M}_{3}\right.$ and $\left.\mathrm{M}_{4}\right)$ significantly increased the $\mathrm{N}$ uptake over the treatment that received RDF alone $\left(\mathrm{M}_{1}\right)$. Among the organics the highest $\mathrm{N}$ uptake by plant was recorded in the treatment $\mathrm{M}_{2}$ with $33.91,132.58,166.10 \mathrm{~kg} \mathrm{ha}^{-1}$ at $30,60,90$ DAT during first year but on par with each other. Similar trend was observed in case of $\mathrm{N}$ uptake by rice straw and grain. Similar trend was observed during second year of the study except by straw in which the treatment $M_{3}$ was inferior to $M_{2}$ statistically. These results were in agreement with the findings of Verma (1991) who found that incorporation of FYM significantly increased the $\mathrm{N}$ uptake of seed and straw compared to other composts. Hossain et al. (2010) also reported higher $\mathrm{N}$ uptake in rice with FYM application over no fertilizer and inorganic fertilizers application.

Table 1 Influence of organics on nitrogen uptake $\left(\mathrm{kg} \mathrm{ha}^{-1}\right)$ at different growth periods of rice

\begin{tabular}{ccccccccccc}
\hline \multirow{2}{*}{ Treatment } & \multicolumn{4}{c}{ 2011-2012 } & \multicolumn{4}{c}{ 2012-2013 } \\
\cline { 2 - 10 } & 30 DAT & 60 DAT & 90 DAT & Straw & Grain & 30 DAT 60 DAT 90 DAT & Straw & Grain \\
\hline $\mathrm{M}_{1}$ - RDF (Control) & 24.06 & 102.51 & 118.84 & 52.51 & 64.26 & 16.79 & 81.94 & 88.50 & 47.90 & 53.01 \\
$\mathrm{M}_{2}$ - FYM 10t ha ${ }^{-1}+$ RDF & 33.91 & 132.58 & 166.10 & 68.09 & 90.69 & 23.17 & 109.90 & 120.80 & 68.80 & 78.90 \\
$\mathrm{M}_{3}$ - Vermicompost 1.5t ha ${ }^{-1}+$ RDF & 31.86 & 121.87 & 152.04 & 64.72 & 86.34 & 22.01 & 99.03 & 116.27 & 60.21 & 69.87 \\
$\mathrm{M}_{4}$ - Green manuring + RDF & 33.65 & 125.97 & 158.12 & 67.35 & 88.97 & 22.43 & 106.08 & 118.98 & 65.91 & 72.39 \\
SEm \pm & 1.311 & 4.131 & 6.131 & 1.739 & 3.832 & 0.749 & 3.728 & 4.643 & 2.296 & 3.008 \\
CD (P: 0.05) & 4.04 & 12.73 & 18.89 & 5.36 & 11.81 & 2.31 & 11.48 & 14.30 & 7.07 & 9.27 \\
CV (\%) & 9.5 & 7.6 & 9.2 & 6.2 & 10.4 & 7.9 & 8.4 & 9.3 & 8.5 & 9.8 \\
\hline
\end{tabular}

The increase in $\mathrm{N}$ uptake could be ascribed to slow and continued supply of the nutrients, coupled with reduced $\mathrm{N}$ losses via denitrification or leaching, which might have improved the synchrony between plant $\mathrm{N}$ demand and supply from the soil (Haile et al. 2012, Tilahun et al. 2013). The best treatment $\left(\mathrm{M}_{2}\right)$ recorded 41.12 and 29.67 per cent higher $\mathrm{N}$ uptake by rice grain and straw, respectively over $100 \%$ NPK alone $\left(M_{1}\right)$ in 2011. Application of organics in combination with inorganic fertilizers, exhibited better response in nutrient uptake over chemical fertilizer due to steady supply of nutrients throughout the growing period of crops (Laxminarayana 2006). These results were in consonance with the findings of Sharma and Mittra (1990) with FYM, Bhandari et al. (1992) with green manuring and Kale et al. (1991) with vermicompost. Kumazava (1984) reported that the immobilization and mineralization of $\mathrm{N}$ in the soil could be regulated by the addition of organic matter to improve the $\mathrm{N}$ uptake by rice.

The highest $\mathrm{N}$ uptake was associated with treatments of NPK applied through organics $+100 \%$ NPK. This might be due to added fertilizers, FYM, green manuring or vermicompost as a better availability source of $\mathrm{N}$ in soil to 


\section{Sources of Nutrients on NPK Uptake by Rice Crop at Various Growth Periods}

rice crop. Poor availability and higher loss of nutrients under RDF alone resulted lower uptake (Mohana Rao et al. 2014). These results were in accordance with the findings of Singh et al. (2006b). The favourable effect of green manuring and FYM in soil and thereby removal of NPK through plant uptake by upland rice was earlier reported by Sharma et al. (2001), Gupta et al. (2006).

\section{$P$ uptake by rice}

Results pertaining in (Table 2) indicated that the $\mathrm{P}$ uptake at 30 DAT, 60 DAT, 90 DAT and maturity was significantly influenced by different organic sources of nutrients during both the years of study and ranged from 8.16 to 11.63 and 20.68 to $29.08 \mathrm{~kg} \mathrm{ha}^{-1}$ by rice straw and grain, respectively in 2011 kharif (Fig 2). Irrespective of growth stage of rice and year of the study the treatments those received FYM, vermicompost or green manuring along with the RDF significantly increased the $\mathrm{P}$ uptake over the treatment received RDF alone. The highest $\mathrm{P}$ uptake as in case of $\mathrm{P}$ content at all growth stages of rice was observed in the treatment $\mathrm{M}_{2}$ with $6.33,19.38,23.81 \mathrm{~kg}$ $\mathrm{ha}^{-1}$ at 30, 60 and 90 DAT of rice respectively during first year of study except 30DAT in 2011 where it was highest in $\mathrm{M}_{4}$. Second highest of $\mathrm{P}$ uptake was recorded by green manuring incorporated treatment $\left(\mathrm{M}_{4}\right)$ with $6.41,18.41$, $22.36 \mathrm{~kg} \mathrm{ha}^{-1}$ at $30,60,90$ DAT of rice plant, respectively during 2011 kharif. Siddaram et al. (2011) recorded

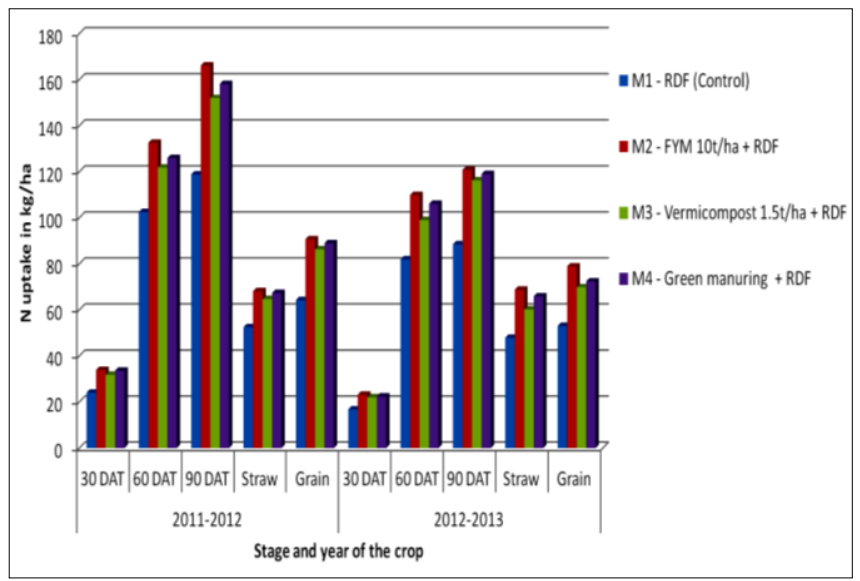

Fig 1 Influence of organics on nitrogen uptake $\left(\mathrm{kg} \mathrm{ha}^{-1}\right)$ at different growth stages of rice significantly higher phosphorus uptake with recommended dose of fertiliser (100:50:50) + 10t of FYM ha ${ }^{-1}$ over control which was on par with $150 \%$ and $200 \%$ recommended dose of nitrogen (RDN). The highest $\mathrm{p}$ uptake by rice grain was recorded in the treatment $\mathrm{M}_{2}\left(29.08\right.$ and $20.76 \mathrm{~kg} \mathrm{ha}^{-1}$ in 2011 and 2012, respectively) followed by $\mathrm{M}_{4}$ (27.16 and $19.79 \mathrm{~kg} \mathrm{ha}^{-1}$ in 2011 and 2012, respectively). Application of $10 \mathrm{t} \mathrm{FYM} \mathrm{ha}{ }^{-1}$ along with $\mathrm{RDF}\left(\mathrm{M}_{2}\right)$ in rice-maize system significantly increased $\mathrm{P}$ uptake by 40.61 and $42.52 \%$ as compared with RDF alone by rice grain and straw respectively in 2011 kharif. These results were in agreement with the findings of Singh et al. (2004). Verma (1991) found that incorporation of FYM significantly increased the N, P and $\mathrm{K}$ uptake of seed and straw. Hossain et al. (2010) also reported higher $\mathrm{P}$ uptake in rice with FYM application over no fertilizer and inorganic fertilizers application. Available $\mathrm{P}$ in soil significantly enhanced due to application of organic manures (Mohana Rao et al. 2014). The increased availability of $\mathrm{P}$ resulted in more uptake of $\mathrm{P}$ by the plant. The $\mathrm{pH}$ of the soil also indicated a positive change i.e. a shift towards neutrality. This positive change enhanced the solubility of different nutrients especially phosphorus in the soil. The form of orthophosphate ion might have converted from $\mathrm{PO}_{4}{ }^{3-}$ to $\mathrm{HPO}_{4}{ }^{2-}$ or even $\mathrm{H}_{2} \mathrm{PO}_{4}^{-}$for short periods, which resulted in increased concentration of $\mathrm{P}$ in the plants. These results are in accordance to the observations of Das (2000), Tilahun et al. (2013).

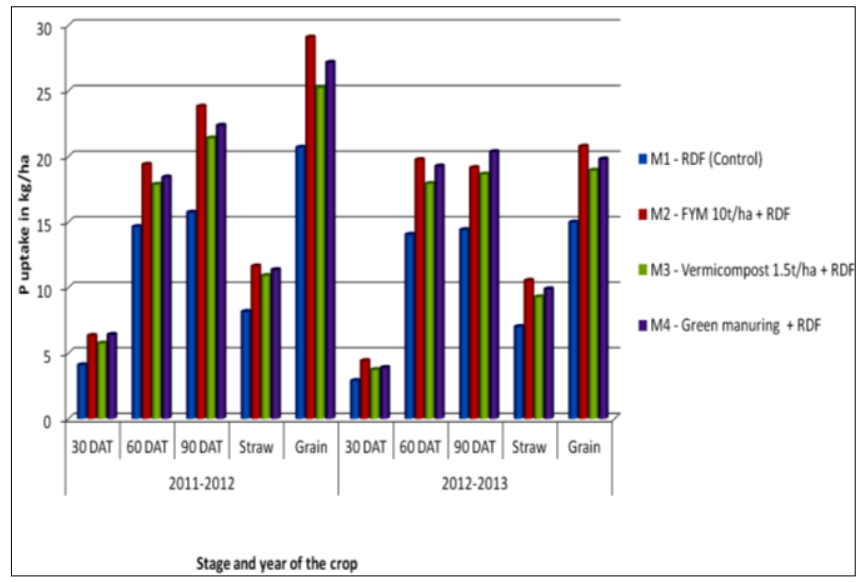

Fig 2 Influence of organics on phosphorus uptake $\left(\mathrm{kg} \mathrm{ha}^{-1}\right)$ at different growth stages of rice

Table 2 Influence of organics on phosphorus uptake $\left(\mathrm{kg} \mathrm{ha}^{-1}\right)$ at different growth periods of rice

\begin{tabular}{cccccccccccc}
\hline \multirow{2}{*}{ Treatment } & \multicolumn{4}{c}{$2011-2012$} & \multicolumn{4}{c}{$2012-2013$} \\
\cline { 2 - 11 } & 30 & 60 & 90 & \multirow{2}{*}{ Straw } & \multirow{2}{*}{ Grain } & 30 & 60 & 90 & \multirow{2}{*}{ Straw } & \multirow{2}{*}{ Grain } \\
\hline $\mathrm{M}_{1}$ - RDF (Control) & 4.09 & 14.63 & 15.73 & 8.16 & 20.68 & 2.89 & 14.04 & 14.40 & 7.01 & 14.98 \\
$\mathrm{M}_{2}$ - FYM 10t ha ${ }^{-1}+$ RDF & 6.33 & 19.38 & 23.81 & 11.63 & 29.08 & 4.41 & 19.74 & 20.50 & 10.53 & 20.76 \\
$\mathrm{M}_{3}$ - Vermicompost 1.5t ha ${ }^{-1}+\mathrm{RDF}$ & 5.75 & 17.86 & 21.39 & 10.90 & 25.25 & 3.73 & 17.92 & 18.64 & 9.28 & 18.93 \\
$\mathrm{M}_{4}$ - Green manuring + RDF & 6.41 & 18.41 & 22.36 & 11.35 & 27.16 & 3.89 & 19.25 & 20.35 & 9.88 & 19.79 \\
SEm \pm & 0.205 & 0.501 & 0.577 & 0.253 & 1.074 & 0.131 & 0.716 & 0.664 & 0.290 & 0.860 \\
CD (P: 0.05) & 0.63 & 1.54 & 1.78 & 0.78 & 3.31 & 0.40 & 2.21 & 2.35 & 0.89 & 2.65 \\
CV (\%) & 8.1 & 6.4 & 6.2 & 5.4 & 9.4 & 7.8 & 9.0 & 8.0 & 7.1 & 10.3 \\
\hline
\end{tabular}


The higher $\mathrm{P}$ uptake attributed to the increased $\mathrm{P}$ availability and increased root growth of the crop (Tilahun et al. 2013). According to Aziz et al. (2010) root growth in plants receiving FYM was higher and hence would increased nutrient uptake. Yassen et al. (2010) further suggested that FYM application increased the transfer of elements between the solid phase and soil solution which again could be a reason for the higher nutrient uptake. It was also indicated that the activity of soil microorganisms under higher FYM applications might had led to increased nutrient uptake (Yassen et al. 2010). The maximum $\mathrm{P}$ uptake was noted when $75 \%$ RDF with vermicompost at the rate of one $\mathrm{tha}^{-1}$ and PSB followed by the integration of $75 \%$ RDF with vermicompost at the rate of one $\mathrm{t} \mathrm{ha}^{-1}$ by Nandinidevi et al . (2013). Yadav et al. (2005) also reported maximum $\mathrm{P}$ uptake when $25 \% \mathrm{~N}$ was substituted by green leaf (Sesbania) manure. Recommended NPK + FYM 10t ha ${ }^{-1}$ followed by $50 \%$ recommended NPK + FYM 10t ha ${ }^{-1}$ resulted in higher nutrient uptake compared to the recommended rate of NPK alone (Chaturvedi and Chandel 2005).

\section{$K$ uptake by rice}

Results presented in (Table 3 ) revealed that $\mathrm{K}$ uptake at 30 DAT, 60 DAT, 90 DAT and maturity was significantly influenced by different organic sources of nutrients during both the years of study and followed the similar trend of $\mathrm{P}$ uptake by rice at various growth stages. K uptake was ranged from 36.09 to $52.75 \mathrm{~kg} \mathrm{ha}^{-1}$ at $30 \mathrm{DAT}, 151.73$ to $207.11 \mathrm{~kg} \mathrm{ha}^{-1}$ at $60 \mathrm{DAT}, 162.02$ to $234.29 \mathrm{~kg} \mathrm{ha}^{-1}$ at 90 DAT, 98.22 to $127.63 \mathrm{~kg} \mathrm{ha}^{-1}$ by straw and 21.94 to $40.38 \mathrm{~kg}$ $\mathrm{ha}^{-1}$ by grain at maturity during 2011-12. The highest $\mathrm{K}$ uptake by rice was recorded by the treatment $\mathrm{M}_{2}$ and the increase was 44.21 and 29.94 per cent over $\mathrm{M}_{1}$ by rice grain and straw, respectively in 2011. Singh et al. (2004) reported that application of $10 \mathrm{t} \mathrm{FYM} \mathrm{ha-1} \mathrm{in} \mathrm{rice-wheat} \mathrm{system}$ significantly increased $\mathrm{K}$ uptake by 7.6 per cent over control. Pradeep et al. (2012) also concluded that application of recommended dose of fertilizer + FYM @ 10t ha ${ }^{-1}$ recorded significantly higher potassium $\left(94.0 \mathrm{~kg} \mathrm{ha}^{-1}\right)$ uptake. Duhan et al. (2001) observed that application of $\mathrm{GM}$, in general, increased the $\mathrm{K}$ uptake in rice grain and straw. In barley, the highest $\mathrm{K}$ uptake was found due to an addition of vermicompost @ 4.5t ha ${ }^{-1}$ along with $60 \mathrm{~kg} \mathrm{~N}$ $\mathrm{ha}^{-1}$ (Kumawat and Jat 2005) which supported these findings. Tiwari et al. (2002) noticed faster rate of mineralization and greater utilization of nutrients through the use of green manuring in combination with chemical fertilizer. Other scientists (Dixit and Gupta, 2000; Selvakumari et al. 2000, Sarwar et al. 2003) also observed increased uptake of $\mathrm{N}, \mathrm{P}$ and $\mathrm{K}$ by various crops when inorganic and organic sources of nutrients in the form of chemical fertilizer, FYM, green manuring and compost were applied to the soil. Similarly the findings of Pattanayak et al. (2001), Yaduvanshi (2001) were again in the same direction of enhanced N, P and $\mathrm{K}$ uptake by different crops. Modak and Chavan (2000) studied the response of rice to FYM in calcareous black soils of Palghar (Thane), the uptake of N, P and $\mathrm{K}$ by grain and straw increased due to application of FYM. Sharma and Sharma (2002) studied the effect of nutrient management on sustainability of rice-wheat cropping system and revealed that FYM @ 10t ha ${ }^{-1}$ increased $\mathrm{N}$ uptake by 38 to $45 \mathrm{~kg} \mathrm{ha}^{-1}, \mathrm{P}$ uptake by 7 to $10 \mathrm{~kg}$ $\mathrm{ha}^{-1}, \mathrm{~K}$ uptake by 25 to42 $\mathrm{kg} \mathrm{ha}^{-1}$. The uptake of NPK by rice plant was highest when fertilizer was applied in combination with vermicompost (Jadhav et al. 1997).

Table 3 Influence of organics on potassium uptake $\left(\mathrm{kg} \mathrm{ha}^{-1}\right)$ at different growth periods of rice

\begin{tabular}{|c|c|c|c|c|c|c|c|c|c|c|}
\hline \multirow{2}{*}{ Treatment } & \multicolumn{5}{|c|}{ 2011-2012 } & \multicolumn{5}{|c|}{$2012-2013$} \\
\hline & $30 \mathrm{DAT}$ & $60 \mathrm{DAT}$ & $90 \mathrm{DAT}$ & Straw & Grain & $30 \mathrm{DAT}$ & $60 \mathrm{DAT}$ & $90 \mathrm{DAT}$ & Straw & Grain \\
\hline $\mathrm{M}_{1}-\mathrm{RDF}$ (Control) & 36.09 & 151.73 & 162.02 & 98.22 & 21.94 & 29.99 & 132.80 & 140.20 & 84.16 & 12.58 \\
\hline $\mathrm{M}_{2}-\mathrm{FYM} 10 \mathrm{tha}{ }^{-1}+\mathrm{RDF}$ & 52.75 & 207.11 & 234.29 & 127.63 & 31.64 & 40.38 & 200.21 & 180.91 & 115.32 & 16.85 \\
\hline $\mathrm{M}_{3}$ - Vermicompost $1.5 \mathrm{tha}^{-1}+\mathrm{RDF}$ & 49.38 & 186.05 & 203.93 & 116.85 & 29.62 & 38.33 & 166.17 & 177.11 & 103.16 & 15.47 \\
\hline $\mathrm{M}_{4}$ - Green manuring $+\mathrm{RDF}$ & 52.08 & 193.47 & 223.44 & 124.83 & 30.19 & 39.17 & 179.65 & 195.19 & 112.34 & 15.85 \\
\hline $\mathrm{SEm} \pm$ & 1.936 & 6.331 & 9.391 & 4.102 & 1.518 & 1.461 & 6.291 & 7.664 & 3.253 & 0.535 \\
\hline $\mathrm{CD}(\mathrm{P}: 0.05)$ & 5.97 & 19.51 & 28.93 & 12.64 & 4.68 & 4.50 & 19.38 & 23.61 & 10.02 & 1.65 \\
\hline $\mathrm{CV}(\%)$ & 9.1 & 7.7 & 10.2 & 7.8 & 12.0 & 8.8 & 8.3 & 9.9 & 7.0 & 7.9 \\
\hline
\end{tabular}

Application of organics along with the RDF $\left(\mathrm{M}_{2}, \mathrm{M}_{3}\right.$ and $\mathrm{M}_{4}$ ) significantly increased the $\mathrm{N} \mathrm{P}$ and $\mathrm{K}$ uptake over the treatment that received $\mathrm{RDF}$ alone $\left(\mathrm{M}_{1}\right)$. Among the organics the highest N P and K uptake by plant was recorded in the treatment $\mathrm{M}_{2}$ where the $100 \%$ NPK was applied along with 10t FYM ha ${ }^{-1}$ followed by $\mathrm{M}_{4}(100 \%$ NPK + Green manure in situ). Similar trend was observed in case of $\mathrm{N} \mathrm{P}$ and $\mathrm{K}$ uptake by rice straw and grain.

\section{LITERATURE CITED}

Ayalew A and Dejene T. 2012. Combined application of organic and inorganic fertilizers to increase yield of barley and improve soil properties at fereze in southern Ethiopia. Innovative Systems Design and Engineering 3(1): 25-35.

Aziz T, Ullah S, Sattar A, Nasim M, Farooq M and Mujtabakhan M. 2010. Nutrient availability and maize (zea mays) growth in soil amended with organic manures. International Journal of Agriculture and Biology 12(4): 621-624.

Bhandari A L, Sood, Anil, Sharma K N and Rana D S. 1992. Integrated nutrient management in rice-wheat system. Journal of Indian Society of Soil Science 40(4): 742-747. 


\section{Sources of Nutrients on NPK Uptake by Rice Crop at Various Growth Periods}

Chaturvedi S and Chandel A S. 2005. Influence of organic and inorganic fertilization on soil fertility and productivity of soybean (Glycine max). Indian Journal of Agronomy 50: 311-313.

Das P K, Jena M K and Sahoo K C. 2002. Effect of integrated application of vermicompost and chemical fertilizer on growth and yield of paddy in red soil of south eastern Ghat zone of Orissa. Environment and Ecology 20(1): 13-15.

Dixit K G and Gupta B R. 2000. Effect of FYM, chemical and bio-fertilizers on yield and quality of rice and soil properties. Journal of Indian Society of Soil Science 48(4): 773-780.

Duhan B S, Kumar V, Singh N, Khera A P, Kumar V and Singh N. 2001. Effect of manuring on the yield and uptake of potassium in rice. Crop Research 22(3): 330-334.

Gupta V, Sharma R S and Vishwakarma S K. 2006. Long-term effect of integrated nutrient management on yield sustainability and soil fertility of rice (Oryza sativa) - wheat (Triticum aestivum) cropping system. Indian Journal of Agronomy 51(3): 160-164.

Haile D, Dechassa N and Ayana A. 2012. Nitrogen use efficiency of bread wheat, effects of nitrogen rate and time of application. Journal of Soil Science and Plant Nutrition, Ahead of prints E-publication, 25-Sep-2012.

Hossain A T, Rahman F, Saha P K and Solaiman A R M. 2010. Effects of different aged poultry litter on the yield and nutrient balance in boro rice cultivation. Bangladesh Journal of Agricultural Research 35(3): 497-505.

Jackson M L. 1973. Soil chemical analysis. Prentice Hall of India Private Ltd., New Delhi. pp 134-182.

Jadhav A D, Talashilkar S C and Powar A G. 1997. Influence of conjunctive use of FYM, vermicompost and urea on growth and nutrient uptake in rice. Journal of Maharashtra Agricultural Universities 22(2): 249-250.

Kale R D, Bano K and Satyavati G P. 1991. Influence of vermicompost application on growth and yield of cereals, vegetables and ornamental plants. Final report of KSCST project no. 67-04/verm/34b (3478), Bangalore: 87.

Kumar N, Verma L P, Sing R and Prasad K. 2001. Soil properties, nutrient uptake and productivity of rice under integrated nutrient management system. Annals of Plant and Soil Research 3(1): 54-57.

Kumawat P D and Jat N L. 2005. Effect of organic manure and nitrogen fertilization on productivity of barely (Hordeum vulgare). Indian Journal of Agronomy 50: 200-202.

Kumazava K. 1984. Beneficial effects of organic matter on rice growth and yield in Japan. Organic Matter and Rice, IRRI, Los Bonos, Philippines. pp 431-443.

Laxminarayana K. 2006. Efffect of integrated use of inorganic and organic manures on soil properties, yield and nutrient uptake of rice in Ultisol of Mizoram. Journal of Indian Society of Soil Science 54: 120-123.

Mithun S, Mondal S S, Acharya D and Sanjoy S. 2007. Effect of integrated nutrient management on productivity and quality of basmati rice (Oryza sativa). Oryza 44(2): 125-129.

Modak S J and Chavan K N. 2000. Response of rice to various levels of zinc and iron with and without FYM in black calcareous soil. Madras Agricultural Journal 86(4/6): 206-209.

Nandinidevi K, Singh T B, Herojitsingh A, Singh N B and Diana S. 2013. Influence of inorganic, biological and organic manures on nodulation and yield of soybean (Glycine max) and soil properties. Australian Journal of Crop Science 7(9): 1407-1415.

Olsen S R, Code C L, Watanable F S and Dean L A. 1954. Estimation of available phosphorus in soils by extraction with sodium bicarbonate. United States Development Agency Circular Number 939.

Patra A K, Nayak B C and Mishra M M. 2000. Integrated nutrient management in rice (Oryza sativa) - wheat (Triticum aestivum) cropping system. Indian Journal of Agronomy 45(3): 453-457.

Pattanayak S K, Mishra K N, Jena M K and Nayak R K. 2001. Evaluation of green manure crops fertilized with various phosphorus sources and their effect on subsequent rice crop. Journal of the Indian Society of Soil Science 49(2): 285291.

Piper C S. 1966. Soil and plant analysis. Hans Publishers, Bombay. pp 368.

Pradeep G, Channanaik D, Rajanna G A, Sannathimmappa H G, Ramesha Y M and Veeresha 2012. Economics and nutrient uptake of rice (Oryza sativa) as influenced various levels of FYM and cattle urine application in Bhadra command area of Karnataka. Crop Research 43(1/3): 10-14.

Sarwar G, Hussain N, Mujeeb F, Schmeisky H and Hassan G. 2003. Bio-compost application for the improvement of soil characteristics and dry matter yield of Lolium perenne (Grass). Asian Journal for Plant Science 2(2): 237-241.

Selvakumari G, Baskar M, Jayanthi D and Mathan K K. 2000. Effect of integration of fly ash with fertilizers and organic manures on nutrient availability, yield and nutrient uptake of rice in Alfisols. Journal of Indian Society Soil Science 48(2): 268-278.

Sharma A R and Mittra B N. 1990. In rice based cropping system in eastern India, organic manure should be combined with chemical fertilizer. Indian Farming 40(9): 40-42.

Sharma R P, Bali S V and Gupta D K. 2001. Soil fertility and productivity of rice - wheat cropping system in an Inceptisol as influenced by integrated nutrient management. Indian Journal of Agricultural Sciences 71: 82-86.

Sharma S K and Sharma S N. 2002. Integrated nutrient management for sustainability of rice (Oryza sativa) - wheat (Triticum aestivum) cropping system. The Indian Journal of Agricultural Sciences 72(10): 573-576. 
Siddaram M K, Manjunatha B N, Jagadeesha N, Basavaraja M K and Ramulu. 2011. Effect of nitrogen levels through organic sources on dry matter production and nutrient uptake of irrigated aerobic rice (Oryza sativa L.). Mysore Journal of Agricultural Sciences 45(1): 191-193.

Singh S K, Verma S C and Singh R P. 2004. Residual effect of organic and inorganic sources of nutrients in lowland rice on succeeding lentil. Indian Journal of Agricultural Research 38(2): 121-125.

Srinivasan S and Angayarkanni A. 2000. Effect of INM on yield and nutrient uptake by rice in STCR experiment. Agricultural Science Digest 28(2): 130-132.

Tilahun T F, Nigussie D R, Wondimu B and Setegn G. 2013. Effect of farm yard manure and inorganic fertilizers on the growth, yield and moisture stress tolerance of rainfed lowland rice. American Journal of Research Communication 1(4): 274-301.

Tiwari A, Dwivedi A K and Dikshit P R. 2002. Long-term influence of organic and inorganic fertilization on soil fertility and productivity of soybean-wheat system in a Vertisol. Journal of Indian Society of Soil Science 50: 472-475.

Verma T S. 1991. Influence of Lantana, Eupatorium and Farm yard manure on paddy crop. Oryza 28: 177-183.

Yadav M P, Aslam M and Kushwaha S P. 2005. Effect of integrated nutrient management on rice (Oryza sativa) - wheat (Triticum astivum) cropping system in central plain zone of Uttar Pradesh. Indian Journal of Agronomy 50: 89-93.

Yaduvanshi N P S. 2001. Effect of five years of rice-wheat cropping and NPK fertilizers use with and without organic and green manures on soil properties and crop yields in a reclaimed sodic soil. Journal of the Indian Society of Soil Science 49(4): 714-719.

Yassen A, Khaled A, Sahar S M and Zaghloul M. 2010. Response of wheat to different rates and ratios of organic residues on yield and chemical composition under two types of soil. Journal of American Science 6(12): 858-864. 